\section{Commentary: A stitch in time saves nine, but medical therapy makes that stitch shine}

\author{
Moritz C. Wyler von Ballmoos, MD, PhD, MPH, ${ }^{\mathrm{a}, \mathrm{b}}$ \\ and G. Hossein Almassi, MD
}

Ischemic cardiomyopathy (ICM) is a leading cause of morbidity and mortality across the globe, with a rapidly growing number of affected patients in the US and a poor prognosis overall. ${ }^{1}$ Median survival is not substantially greater than 5 years in patients with ICM and reduced ejection fraction $(\mathrm{EF})^{2}{ }^{2}$ Although primary prevention of coronary artery disease (CAD) is the sole hope of effectively lessening the societal burden of this disease, effective secondary prevention can preserve some quality and quantity of life in patients diagnosed with ICM.

Surgical and percutaneous revascularization have prolonged and improved the lives of millions of patients with $\mathrm{CAD}$ and ICM over the last 40-plus years; however, the therapeutic effectiveness of myocardial revascularization has increased in only limited increments despite advances in technology and technique. Yet survival of patients with ICM has continued to increase, attributable in large part to the progress made in the medical management of CAD and ICM.

In this edition of the Journal, Farsky and colleagues ${ }^{3}$ report a post hoc analysis of the 10-year data from the prospective randomized Surgical Treatment for Ischemic Cardiomyopathy (STICH) trial. They compare optimal medical therapy (OMT) with non-OMT in both arms of the trial (coronary artery bypass grafting $[\mathrm{CABG}]+$ medication and medication alone). Using an a priori definition of OMT

From the a Department of Cardiothoracic Surgery, DeBakey Heart \& Vascular Center, Houston, Tex; ${ }^{\mathrm{b}}$ Department of Cardiothoracic Surgery, DeBakey Heart and Vascular Center, Weill Cornell Medicine, New York, NY; and ${ }^{\mathrm{c}}$ Division of Cardiothoracic Surgery, Department of Surgery, Medical College of Wisconsin, Milwaukee, Wis.

Disclosures: The authors reported no conflicts of interest.

The Journal policy requires editors and reviewers to disclose conflicts of interest and to decline handling or reviewing manuscripts for which they may have a conflict of interest. The editors and reviewers of this article have no conflicts of interest.

Received for publication Dec 30, 2020; revisions received Dec 30, 2020; accepted for publication Dec 30, 2020; available ahead of print Jan 9, 2021.

Address for reprints: G. Hossein Almassi, MD, Division of Cardiothoracic Surgery, HUB, 5th floor, Medical College of Wisconsin, 8701 Watertown Plank Rd, Milwaukee, WI 53226 (E-mail: halmassi@mcw.edu).

J Thorac Cardiovasc Surg 2022;164:1900-1

0022-5223/\$0.00

Published by Elsevier Inc. on behalf of The American Association for Thoracic Surgery

https://doi.org/10.1016/j.jtcvs.2020.12.139

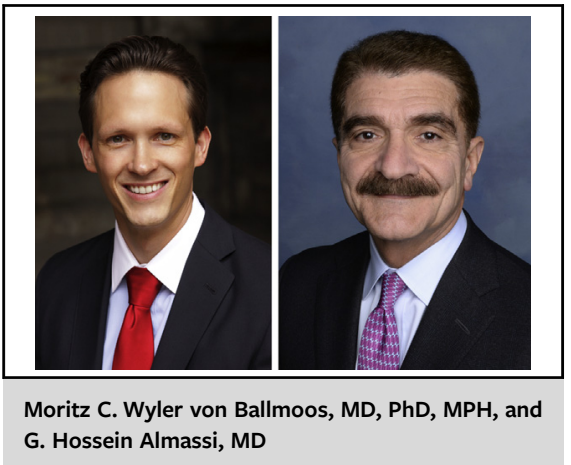

CENTRAL MESSAGE

Ensuring optimal medical therapy through a team approach will improve the long-term outcomes of patients with ischemic heart disease undergoing coronary artery bypass grafting.

and patient self-reported data on drug compliance, they show a substantial benefit of OMT over non-OMT in both arms of the trial that enrolled patients with an EF $<35 \%$.

The original publication of the 10-year STICH data ${ }^{2}$ showed an absolute mortality reduction of $7.2 \%$ with CABG over medical management alone for a number needed to treat of 14 . The absolute mortality reduction in this study, comparing the worst of both worlds (ie, nonOMT alone) to the best of both worlds (CABG + OMT) was $17 \%$, cutting the NNT down to 6 .

These findings are not necessarily surprising, but they dramatically show the importance of OMT in this vulnerable patient population. Trials of long-acting beta-blockers (CAPRICORN, ${ }^{4}$ MERIT-HF ${ }^{5}$ ), angiotensin-converting enzyme inhibitors (TRACE, ${ }^{6} \mathrm{SAVE}^{7} \mathrm{AIRE}^{8}$ ), angiotensin receptor blockers $\left(\mathrm{VALIANT}^{9}\right.$ ), mineralocorticoid receptor antagonists (EPHESUS ${ }^{10}$ ), and angiotensin receptor neprilysin inhibitor (PARADIGM-HF ${ }^{11}$ ) have shown significantly improved survival in patients with heart failure with reduced EF and are an integral part of guidelinedirected medical therapy. ${ }^{12} \mathrm{CABG}$, although improving myocardial blood supply and potentially preventing future myocardial infarction, is ultimately limited in its ability to remodel the left ventricle, reduce wall tension, and improve systolic and diastolic function in ICM. Unfortunately, adherence to even simpler medicine regiments in patients with normal EF undergoing $\mathrm{CABG}$ is notoriously poor. ${ }^{13}$ 
Few important lessons should be taken away from this study: (1) many patients are receiving suboptimal medical therapy (at baseline), and we must do better both before and after $\mathrm{CABG}$; (2) improving and maintaining drug compliance is hard work but can be done-patient education is key and pays dividends down the road; and (3) physicians and patients alike must understand that CAD and ICM are complex, multifactorial, chronic disease processes, and a band aid will not suffice. A stich in time is part of the solution to improve survival, but it should be shined with sustained OMT.

\section{References}

1. Benjamin EJ, Muntner P, Alonso A, Bittencourt MS, Callaway CW, Carson AP, et al. Heart disease and stroke statistics-2019 update: a report from the American Heart Association. Circulation. 2019;139:e56-528.

2. Velazquez EJ, Lee KL, Jones RH, Al-Khalidi HR, Hill JA, Panza JA, et al. Coronary-artery bypass surgery in patients with ischemic cardiomyopathy. $N$ Engl $J$ Med. 2016;374:1511-20.

3. Farsky PS, White J, Al-Khalidi HR, Sueta CA, Dabrowski R, Djokovic L, et al. Optimal medical therapy with or without surgical revascularization and longterm outcomes in ischemic cardiomyopathy. J Thorac Cardiovasc Surg. 2022; 164:1890-9.e4.

4. Dargie HR, the CAPRICORN Investigators. Effect of catvedilol on outcome after myocardial infarction in patients with left-ventricular dysfunction: the CAPRICORN randomized trial. Lancet. 2001;357:1385-90.
5. Fagerberg B, the MERIT-HF Study Group. Effect of metoprolol CR/XL in chronic heart failure: metoprolol CR/XL randomized intervention trial in congestive heart failure (MEERIT-HF). Lancet. 1999;353:2001-7.

6. Kober L, Torp-Pedersen, Carlsen JE, Bagger H, Eliasen P, Lynborg K, et al. A clinical trial of the angiotensin-converting-enzyme inhibitor trandolapril in patients with left ventricular dysfunction after myocardial infarction. Trandolapril Cardiac Evaluation (TRACE) study Group. N Engl J Med. 1995;333:1670-6.

7. Pfeffer MA, Braunwald E, Moyé LA, Basta L, Brown EJ, Cuddy TE, et al. Effect of captopril on mortality and morbidity in patients with left ventricular dysfunction after myodardial infarction: results of the survival and ventricular enlargement trial. N Engl J Med. 1992;327:669-77.

8. Ball SG, the AIRE Study Group. Effect of ramipril on mortality and morbidity of survivors of acute myocardial infarction with clinical evidence of heart failure. Lancet. 1993;342:821-8.

9. Pfeffer MA, McMurray JJV, Velazquez EJ, Rouleau J-L, Kober L, Maggioni A, et al. Valsartan, captopril, or both in myocardial infarction complicated by heart failure, left ventricular dysfunction, or both (VALIANT trial). $N$ Engl J Med. 2003;349:1893-906.

10. Pitt B, Williams G, Remme W, Martinez F, Lopez-Sendon J, Zannad F, et al. The EPHESUS trial: eplerenon in patients with heart failure due to systolic dysfunction complicating acute myocardal infarction. Cardiovasc Drugs Ther. 2001;15 79-87.

11. McMurray JJV, Packer M, Desai A, Gong J, Lefkowitz MP, Rizkala AR, et al. Angiotensin-neprilysin inhibition versus enalapril in heart failure: PARADIGM-HF. N Engl J Med. 2014;371:993-1004.

12. Elgendy IY, Mahtta D, Pepine CJ. Medical therapy for heart failure caused by ischemic heart disease. Circ Res. 2019;124:1520-35.

13. Pinho-Gomes A-C, Azevedo L, Ahn J-M, Park S-J, Hamza TH, Farkouh ME et al. Compliance with guideline-directed medical therapy in contemporary coronary revascularization trials. J Am Coll Cardiol. 2018;71:591-602.

\section{Commentary: Just what the doctor ordered: The as-yet unrealized gains of optimal medical therapy for ischemic cardiomyopathy}

\author{
David D. Yuh, MD, FACS, FACC
}

In their post hoc analysis of data obtained from the Surgical Treatment for Ischemic Heart Failure (STICH) trial, Farsky and colleagues ${ }^{1}$ substantiate the benefit of optimal

\footnotetext{
From the Department of Surgery, Stamford Hospital, Stamford, Conn. Disclosures: The author reported no conflicts of interest.

The Journal policy requires editors and reviewers to disclose conflicts of interest and to decline handling or reviewing manuscripts for which they may have a conflict of interest. The editors and reviewers of this article have no conflicts of interest.

Received for publication Jan 1, 2021; revisions received Jan 1, 2021; accepted for publication Jan 4, 2021; available ahead of print Jan 13, 2021.

Address for reprints: David D. Yuh, MD, FACS, FACC, Department of Surgery, Stamford Hospital, One Hospital Plaza, PO Box 9317, Stamford, CT 06902 (E-mail: DYuh@stamhealth.org).

J Thorac Cardiovasc Surg 2022;164:1901-2

$0022-5223 / \$ 36.00$

Copyright (c) 2021 by The American Association for Thoracic Surgery

https://doi.org/10.1016/j.jtcvs.2021.01.007
}

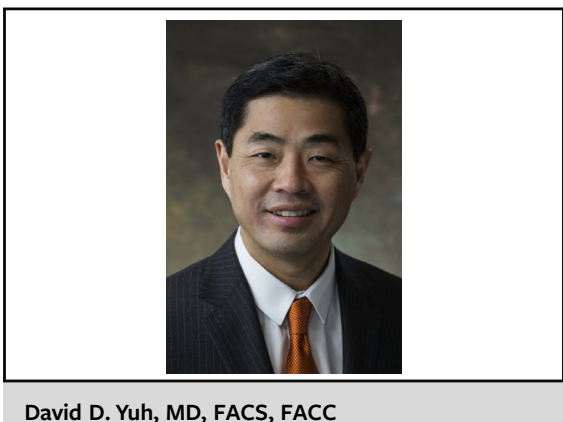

CENTRAL MESSAGE

The long-term survival benefit conferred by optimal medical therapy in coronary bypass patients with ischemic cardiomyopathy emphasizes the importance of increasing medical compliance. 